\title{
Rejtőzködő városi menekültek Bangkokban
}

\section{A nemzetközi menekültjogi és emberi jogi szabályozás kihívásai Thaiföldön}

\section{SOLYMÁRI DÁNIEL ${ }^{1}$ - TAMÁSSY BENCE ${ }^{2}$}

A thaiföldi bevándorlási törvény értelmében az országba érkezö menekültek illegális bevándorlónak minösülnek. Ennek alapvetö oka, hogy a délkeletázsiai királyság máig nem csatlakozott a genfi menekültügyi egyezményhez, így menekültkérelmeket nem fogad, e státuszt nem ismeri el. A jogszerütlenül tartózkodókat a rendörség idegenrendészeti őrizetbe veheti, ellenük büntetöeljárást kezdeményezhet. E nemzetközi dialógusban vitális téma azonban Magyarországon kevésbé ismert. Munkánkban a thai menekültügyi valóságot érintö helyi és nemzetközi jogi kereteket tekintjük át és mutatunk rá a thai jogalkalmazás révén kialakult humanitárius válságra. Irásunk fókusza arra a kérdésre irányul, hogy a genfi menekültügyi egyezmény meghatározása alapján menekültnek minősülö emberek milyen jogvédelemre számíthatnak egy olyan országban, amely nem rendelkezik menekültügyi rendszerrel.

Kulcsszavak: városi menekültek, thaiföldi menekültjog, non-refoulement elve, ázsiai migráció

\section{Bangkok's Hidden Urban Refugees}

Challenges to International Refugee and Human Rights Regulation in Thailand

According to the Thai Immigration Act, refugees arriving to the country are illegal immigrants. The main reason for this is that the Kingdom has not yet ratified the 1951 Refugee Convention, thus it does not accept refugee applications, it does not recognise this status. The police can detain illegal residents and can initiate criminal proceedings against them. However, this vital topic of international dialogue is less known in Hungary. In our work, we review the local and international legal framework affecting the reality of the Thai refugee crisis, and point out the humanitarian crisis that has arisen through the enforcement of Thai law. Our paper is focused on the issue of

1 Nemzetközi kapcsolatok vezető, Magyar Máltai Szeretetszolgálat; Pécsi Tudományegyetem BTK Politikatudományi Doktori Program, e-mail: solymari.daniel@maltai.hu

2 Nemzetközi kapcsolatok referens, Magyar Máltai Szeretetszolgálat. 
legal protection that people who qualify as refugees under the Geneva Convention on Refugees can expect in a country that has not ratified the Convention and does not have an asylum system.

Keywords: urban refugees, Thailand immigrants, asylum seekers in Bangkok, non-refoulement in Thailand

\section{Bevezető gondolatok}

Thailföld a nemzetközi turisztikai és üzleti célú utazások egyik kiemelt területi központja. Az ázsiai csendes-óceáni térségben csak Kína előzi meg a Turisztikai Világszervezet, a UNWTO külföldiek beutazásait összegző évenkénti összeállítás, úgynevezett turisztikai kompendium adatai szerint. ${ }^{3} \mathrm{E}$ kimutatás alapján a térség mintegy 360 millió turistájából, 2019-ben Thaiföldre megközelítőleg 40 millióan érkeztek, ami közel duplája a középmezőny országaiba utazókhoz képest. ${ }^{4} \mathrm{~A}$ délkelet-ázsiai királyság az 1990-es évek eleje óta vezeti a regionális rangsort: az 1990 és 1995 közötti periódus ötmilliós évenkénti látogatószáma óta különösebb visszaesés vagy stagnálás nélkül emelkedett e görbe napjaink, a koronavírus okozta világjárvány hatására bevezetett korlátozásokig. ${ }^{5}$ De nem csupán a bangkoki metropolis üzleti lehetőségeit vagy az ország déli területeinek üdülőközpontjait keresők választják Thaiföldet utazásuk céljául. Menekültek tömege érkezik ide minden évben, élve annak lehetőségével, hogy az ország (serkentve ezzel az egyéb látogatásokat) igen nagyvonalúan, könnyen ad turisztikai célú vízumot, a kérvényező nemzetiségétől függetlenül, különösebb korlátozás, megkötés nélkül. Ellentétben a térség több, hasonló kapacitásokkal rendelkező országával, egy szubszaharai afrikai, pakisztáni, mianmari vagy épp kínai menekült csak a legritkább esetben tudna legális úton Indiába, Japánba vagy éppen Ausztráliába jutni. A liberális vízumszabályozás okán ezért sokaknak Thaiföld a legközelebbi biztonságos ország, ahova turistavízummal beutazhatnak. ${ }^{6}$ Jogszerű tartózkodásuk azonban vízumuk lejárta után már nem biztosított.

3 World Tourism Organization: Compendium of Tourism Statistics, Data 2014 - 2018, 2020 Edition (2020); UNWTO: Thailand: Country-specific: Basic indicators (Compedium) 2015-2019 (2020. november).

$4 \quad$ Ezek az adatok a koronavírus okozta világjárvány okán drasztikusan lecsökkentek. A beutazási korlátozások tekintetében Thaiföld a térség legszigorúbb országai közé tartozott a pandémia alatt; a légi úton történő beutazások csak 2021. november 1-jén csökkentek, addig minden látogatónak kéthetes karanténkötelezettsége volt az állam által kijelölt szállodák egyikében.

5 Ministry of Tourism and Sport: Tourism Statistics 2017-2021; World Bank: International tourism, number of arrivals (2019).

6 Doug Bandow: Desperate Pakistani Christians Languish in Thailand. Cato Institute, 2018. október 29. 
Pedig a negyvenmilliós évenkénti látógatóból legalább félmillióan illegálisan tartózkodnak az országban további százezren pedig valamely, az ENSZ Menekültügyi Főbiztossága (a UNHCR) és a thai kormány fenntartásában lévő „menekülttáborban”, befogadó állomáson, úgynevezett detention centre-ben tartózkodnak. ${ }^{7}$ És bizonyára még ennél is többen élnek a közel tízmilliós Bangkok nagyvárosának árnyékvilágában. A thai bevándorlási törvény és idegenrendészeti szabályok értelmében ezek az emberek tehát jogcím nélkül tartózkodnak az országban, ugyanis, mint erre később kitérünk, Thaiföld máig nem csatlakozott a genfi menekültügyi egyezményhez, így menekültkérelmeket nem fogad, e státuszt nem ismeri el. Az országban jogszerütlenül tartózkodók illegális bevándorlók, akiket a rendőrség idegenrendészeti őrizetbe vehet, ellenük büntetőeljárást kezdeményezhet. E központokban illegális menekültek százai, ezrei élnek, gyakran évek óta (bírósági döntéssel vagy anélkül), nem ritkán embertelen körülmények között. A cellákban túlzsúfolva, az éjszakák során (fekvőhely hiányában) ülve, esetekben a falhoz láncolva, minimális ellátással. ${ }^{8}$ Számukra elsősorban a civil és egyházi, hit alapú segélyszervezetek nyújtanak humanitárius támogatást és jogsegélyt. E fogvatartások ugyanis gyakran jogszerütlenek, sokszor éveken át tartanak, a körülmények pedig az emberi méltóságot súlyosan sértik.

Jelen írásban a Magyar Máltai Szeretetszolgálat és a Thaiföldi Jezsuita Menekültszolgálat által az országban évek óta végzett munka tapasztalatai alapján foglaljuk össze azt a törvényi és szabályozásbéli hátteret, amely a segélymunka, jogsegélyszolgálat, konzuli tevékenység és a humanitárius diplomácia alapjait, kereteit jelenti. A téma egyre gyakrabban szerepel a nemzetközi jogi és segélyezési diskurzusban, ezek mutatnak rá a thaiföldi helyzet elfogadhatatlanságára. Magyar nyelven azonban még nem igen dolgozták fel a thaiföldi városi menekültek sorsát, küzdelmét. A témának számos aspektusa van: pszichoszociális, lelkipásztori, karitatív, konzuli, geopolitikai. Munkánkban mind közül most a témát érintő helyi és nemzetközi jogi kereteket tekintjük át, és mutatunk rá egy Magyarországon kevésbé ismert, a thai jogalkalmazás révén kialakult humanitárius válságra. Írásunk fókusza arra a kérdésre irányul, hogy a genfi menekültügyi egyezmény meghatározása alapján menekültnek minősülő emberek milyen jogvédelemre számíthatnak egy olyan országban, amely nem ratifikálta az egyezményt és nem rendelkezik menekültügyi rendszerrel. Tanulmányunkban, jóllehet e státusszal nem rendelkező emberekről beszélünk, a menekült kifejezést használjuk. Munkánk megírásához alapvetően az elérhető nemzetközi és thai jogszabályokat, jogi elemzéseket vettük alapul, valamint a humanitárius munka adta személyes tapasztalatainkra és a konzuli munka gyakorlatára reflektálunk.

7 UNHCR: Thailand Factsheet (2016. január).

8 UCA News: Caged like animals: Inside Bangkok's notorious IDC. Union of Catholic Asian News, 2020. január 30. 


\section{Meneküléstörténetek - okok és eredők}

A Thaiföldön élő, közel félmillió jogcím nélkül tartózkodó személynek a fele olyan üldözött, aki menekülni kényszerült hazájából. ${ }^{9}$ Az okok változatosak: autoriter kormányzás, amely fenyegetésként tekint egyik vagy másik vallási csoportra, meghatározó helyi kulturális közösségre (ilyen például Észak-Korea, Eritrea, Szomália, Niger vagy éppen Indiában a hindu nacionalisták); domináns vallás, amely jogi és egyéb eszközökkel kívánja biztosítani saját dominanciáát (mint Pakisztán, Szaúd-Arábia vagy Malajzia blaszfémia alapú fetva-ítéletei); vagy extrém, radikális csoport, terrorszervezet, amely „csupán” megsemmisíteni akarja a másikat (például Nigériában vagy a Közel-Keleten). Keresztények, ahmadijja vagy síta muszlimok egyaránt lehetnek elszenvedői az említett okoknak. Egy valami közös bennük: félelmük megalapozott, üldözöttségük sokszor tényszerü, jogsérelmük súlyos, saját államuk nem tudja, vagy nem is akarja megvédeni őket. A thaiföldi segélymunka során egyházi, civil és a diplomáciai élet szereplőivel együttesen dolgoztak e munka szerzői az elmúlt években, és tapasztalták meg ennek realitását. Személyes találkozások, szociális és konzuli interjúk keretében hallhattunk több száz olyan meneküléstörténetet, amelyek mind az említett migrációs motivációk közé tartoztak. További közös elem volt, hogy Thaiföldről mindenkiben a befogadó ország képe élt és a régió legközelebbi olyan biztonságos helye, ahová turistavízummal beutazhattak. Megérkezésüket követően menekültstátuszért folyamodtak, ám nem létező kategória okán ilyet nem kaptak. Ezt követően az ENSZ Menekültügyi Főbiztosságának védelmét kérték: bizonyíthatóság hiányában (mint nem megalapozott kérelem) azt sem kaptak. 60 napos turistavízumuk lejártát követően mint túltartózkodottak, a thai törvények értelmében illegális bevándorlókká váltak, akik Bangkok nagyvárosának árnyékgazdaságában elhelyezkedve élnek, várakoznak törvényen kívüli állapotban (esetleg már lejárt, otthonról hozott személyes iratokkal). A thai hatóságok (a rendőrség és bevándorlási hivatal) ezeket a személyeket letartóztathatja, és bírósági ítélettel, egyes esetekben anélkül, örizetbe veheti. Jellemzően az egyik bangkoki Immigration Detention Centre-be, IDC-be kerülnek, ahonnan hónapok, évek elmúltával aztán valamely azonos profilú vidéki intézménybe lesznek átszállítva. Férfiak, nők, gyermekek egyaránt. Sokakat tolonceljárás keretében visszaküldenek származási országukba, másokat évekre őrizetben tartanak. Ebben a realitásban dolgoznak az említett segélyszervezetek, próbálnak humanitárius és jogsegélyt nyújtani a sokszorosan kárvallott menekülteknek. Eközben a multilaterális és más nemzetközi szervezetek folyamatosan jelzik e gyakorlat elfogadhatatlanságát. ${ }^{10}$

9 Chris Rogers: The Christians held in Thailand after fleeing Pakistan. BBC News, 2016. február 26.

10 Amnesty International: Thailand: Between a Rock and a Hard Place (2017. szeptember 28.); IOM UN Migration: United Nations Launches Thailand Migration Report 2019 (2019. január 25.) 


\section{Láncmigráció Thaiföldön: történelmi kitekintés}

Napjainkban Ázsia csendes-óceáni térségében Thaiföld és Hongkong számítanak az afrikai, ázsiai és közel-keleti menekültek két, első számú regionális belépési pontjának. Az ázsiai „menekültközpontnak” számító Indiát Malajzia, Thaiföld és Indonézia követi a kelet-ázsiai régióban. ${ }^{11} \mathrm{~A}$ thaiföldi (és hongkongi) migrációs nyomás azonban történelmi okokra vezethető vissza. A korábban gyarmati küzdelmeket folytató térségbeli országok súlyos belső strukturális válságokat éltek át. A függetlenedési harcok Indiában, Pakisztánban vagy éppen Bangladesben, a polgárháború, majd a kulturális forradalom Kínában, az indokínai háború Vietnámban, Laoszban és Kambodzsában, vagy éppen az etnikai harcok Burmában, mind olyan regionális konfliktusok voltak, amelyek jelentős menekültáradatot eredményeztek. ${ }^{12}$ Emlékezhetünk, hogy az 1950-es vietnámi, majd 1990-es évek burmai kríziseit követő thaiföldi menekülthullámokat a világ legsúlyosabb humanitárius válságai között tartják számon. Mindezek olyan taszító (push) tényezők voltak a múltban, amelyek következtében indirekt módon, mára Thaiföld maradt az első számú célállomása a térség jelen konfliktusait elszenvedőknek. Ravenstein nyomán is tudjuk, hogy a migrálók a jelentősebb ipari, kereskedelmi központok, a leggyorsabban fejlődő regionális nagyvárosok felé irányulnak, amely vonzó-/húzó- (pull) erőként hat számukra. ${ }^{13}$ Mindezt felerősíti az 1945-öt követő időszak hatására kialakult menekültattitűd és thaiföldi országkép (vagyis, hogy az ország egyfajta „menekültközpont”), valamint az az informális háló, amely alapvető szerepet játszik a láncmigráció kialakulásában. Miként Hárs Ágnes is megállapította, „a személyes kapcsolatok és a társadalmi hálók vizsgálata lehetővé teszi, hogy az individuális és túlzottan a társadalmi viszonyokkal magyarázó értelmezéseknél alaposabb magyarázatokat adhassunk a migrációs jelenségekre." ${ }^{14}$ Az egykor csónakokon, tutajokon érkező menekültek képét napjainkra felváltotta a légi úton, turistaként érkezők tömege, ami a bangkoki Szuvarnabhumi Nemzetközi Repülőteret a térség egyik legjelentősebb légikikötőjévé tette. A migrációs motivációk eltérők, egy valami azonban azonos: Thaiföld a legkönnyebben megközelíthető térségbeli ország maradt, és máig az első olyan biztonságos regionális célterület, ahová a menekülni kényszerülők turistavízummal beutazhatnak. Azonban a térség migrációs trendje mára összetett hibrid jelenség: leszámítva az olyanokat, mint a rohingya menekültválság, a menekülések döntően érvényes útiokmánnyal, kezdetben legálisan, jellemzően légi úton és egyéni (vagy családi) alapon, nem tömegesen történnek. A jelenségnek azonnal kimutatható

11 European Commission: Thailand, Malaysia, and Indonesia (2019. július 5.); The Global Economy: Refugee population in South East Asia (2020).

12 Supang Chantavanich - Paul Rabe: Thailand and the Indochinese Refugees: Fifteen Years of Compromise and Uncertainty. Southeast Asian Journal of Social Science, 18. (1990), 1. 66-80.

13 Ernst George Ravenstein: The Laws of Migration. Journal of the Statistical Society of London, 48. (1885), 2. 167-235.

14 Hárs Ágnes: A nemzetközi migráció néhány problémájáról. Szakirodalmi áttekintés. Szociológiai Szemle, 2. (1992), 2. 123-137. 
karaktere nincs, összetétele vegyes, menekültügyi hatása sok esetben csak hónapokkal az országba való érkezést követően figyelhető meg.

Napjainkban a Thaiföldre érkező menekültek több mint 40 különböző országból származnak. Életük első időszakában gyakran tartalékokból élnek. Turistavízumukat már az interneten keresztül intézhetik, amelynek birtokában 60 napig legálisan tartózkodnak az országban. Ezt követően túltartózkodottnak minősülnek, a thai törvények értelmében illegális bevándorlók. Ezek a menekültcsoportok karakterükben tehát alapvetően térnek el a korábbi korok válságainak kárvallottjaitól. Nem is mindenki érkezik menekülési háttérrel, sokan olyan alkalmi munkavállalók, szerencsét próbálók, akik személyes gazdasági okok következtében válnak illegális tartózkodóvá, okirat nélküli „hajléktalanná”. Jelen munkában azonban elsősorban olyan menekültekkel foglalkozunk, akik hazájukban faji, vallási, etnikai okból valós üldöztetésnek voltak kitéve, Thaiföldet mint legközelebbi biztonságos országot érték el, ott menekültkénti elismerésüket kérték, de konfliktusba kerülve a helyi jogi és szabályozási gyakorlattal; státusz nélküli, illegális városi menekültekké váltak, kitéve az állami hatóságok és illegális csoportok abúzusainak.

\section{A menekültjog délkelet-ázsiai gyakorlata}

Jóllehet az ENSZ emberi jogi egyezményei által védett emberi jogok egyetemesek, az egyes kontinensek emberi jogokkal kapcsolatos jogfejlődése eltérően alakult. Ázsia az utóbbi évtizedekig lemaradásban volt e téren, ennek okait keresve Környei Ágnes úgy fogalmazott, hogy:

„[A]z egyén jogainak intézményes védelme az új társadalmi változásokkal szemben igen gyenge Ázsiában. Egyrészt a gyors gazdasági növekedés előtt az ázsiai társadalmak alapvetően tradicionálisak voltak, amelyekre ugyan hatottak néhány nyugati gondolkodó nézetei, és nyugati jogrendszert, koncepciókat is elfogadtak, de az egyén jogait nem sikerült átültetni. Másrészt a gazdasági növekedés egyik oka éppen a fegyelem és a tömegek munkaetikájának bekapcsolása a gazdasági tevékenységbe, amely nem tette lehetővé az egyéni szabadság és emberi jogok kiteljesülését. Harmadrészt az ázsiai gazdasági növekedés nem járt együtt az emberi jogok védelmét szolgáló intézményrendszer kialakításával."15

A Délkelet-ázsiai Nemzetek Szövetségének a tevékenységében is tetten érhető a fent részletezett vonakodás az emberi jogok nyugati koncepciójától: jól példázza ezt az emberi jogok „univerzális természetét” elismerő és egyúttal azt relativizáló Bangkoki Nyilatkozat is. Ahogy az akkori thaiföldi miniszterelnök, Chuan Leekpai fogalmazott:

15 Környei Ágnes: Ázsia és az emberi jogok. In Emberi jogok a nemzetközi kapcsolatokban. Piliscsaba, Pázmány Péter Katolikus Egyetem, 2011. 218-221. 
„[T]ermészetes, hogy az alapvető emberi jogok alkalmazásának megközelítései a társadalmi-gazdasági, a történelmi és a kulturális hátterek és feltételek szerint változnak. Az emberi jogok egyetemességének előmozdítása hatékonyabb lenne, ha az ilyen különbségek egyértelmű elismerésre kerülnének. Az emberi jogok változásainak elsősorban belülről kell eredniük, nem pedig külső kényszerből. Emellett, ha békések és fenntarthatóak akarnak lenni, az emberi jogoknak saját tempójukban kell fejlődniük." ${ }^{16}$

Az ezredforduló óta mindenesetre lassú fejlődés figyelhető meg az emberi jogokhoz való hozzáállás vonatkozásában. 2009-ben megalakult a Délkelet-ázsiai Nemzetek Szövetsége Emberi Jogi Kormányközi Bizottsága (AICHR) nevü konzultatív, kormányközi testület, az emberi jogok regionális promóciójához és védelméhez kapcsolódó 14 mandátummal és funkcióval. A Bizottság 14 taggal rendelkezik, akiket a tagállamok jelölnek hároméves, egyszer megújítható mandátummal. A Bizottság elnöke az ASEAN soros elnöki tisztét betöltő tagállam képviselöje. Évente legalább kétszer, átlagosan hatszor ülésezik, döntéshozatala konzultációra és konszenzusra épül. A Bizottság évente jelentést tesz az ASEAN Külügyminiszteri Értekezletnek. A civil szervezetekkel való kapcsolattartás az AICHR a civil társadalmi szervezetekkel fenntartott kapcsolatairól szóló, az ENSZ Gazdasági és Szociális Tanácsának (ECOSOC) NGO-k számára kidolgozott irányelvei alapján 2015-ben elfogadott iránymutatásai szerint történik. A 2014-es bangkoki regionális emberi jogi mechanizmusokkal foglalkozó workshop kivételével az AICHR nem tart fent rendszeres kooperációt más, regionális emberi jogi mechanizmusokkal, ám az ENSZ számos szakosított szervével és ügynökségével igen. Jóllehet az AICHR az ASEAN „átfogó emberi jogi intézménye", a szervezeti struktúrában a Külügyminiszteri Értekezlet (AMM) alá van rendelve, és konzultatív jogköre van. Önálló működését az is korlátozza, hogy azt az ASEAN Közösség szerves részeként definiálják. ${ }^{17}$

A Genfi Menekültügyi Egyezményt a délkelet-ázsiai térség országai közül csupán Kambodzsa, a Fülöp-szigetek és a Kelet-timori Demokratikus Köztársaság fogadta el. A régió országainak zöme semmilyen menekültügyi szabályozással nem rendelkezik, noha a 47 tagállamot tömörítő Ázsiai-Afrikai Jogi Tanácsadó Szervezet (Asian-African Legal Consultative Organization, AALCO) már az 1960-as években megtette az első lépéseket. Az AALCO 1966-os bangkoki ülésén fogadta el a jogilag nem kötelező erejü Bangkok Principles on Status and Treatment of Refugees elnevezésű szabályrendszert, amelyet 1970-ben kiegészítettek a „visszatérés jogával” (right to return), majd 1987-ben a „tehermegosztás alapelvével” (principles of burdensharing). Az AALCO Titkárságának és az UNHCR-nek többéves munkáját követően átdolgozták a szabályrendszert, amelyet 2001-ben Revised Bangkok Principles néven

16 Chuan Leekpai: Opening Statement - Regional Meeting for Asia, United Nations World Conference on Human Rights. Bangkok, Thaiföld, 1993. március 29. - április 2. UN Digital Library, 1993.

17 Szakáli Máté: Az emberi jogok egyetemességének dilemmája és a délkelet-ázsiai jogvédelmi mechanizmus evolúciója. PEACH Mühelytanulmányok, (2018), 20. 1-33. 
publikáltak. ${ }^{18}$ Sajnos sem az eredeti, sem pedig az átdolgozott kiadás esetében sem járt sikerrel az a célkitűzés, hogy a szabályrendszer elfogadása tagállami menekültjogi rezsimek kidolgozásához vezessen. ${ }^{19}$ Ennek oka a már említett, a nyugati jogfejlődéssel kapcsolatos elzárkózó magatartás mellett az 1945 után a régióban kitört fegyveres konfliktusok nyomán elharapózó menekültválságok miatti félelem volt.

Mindezek eredményeképpen csupán jogilag nem kötelező érvényű deklarációkról beszélhetünk e téren: 2012-ben az ASEAN elfogadta az Emberi Jogi Nyilatkozatot (ASEAN Human Rights Declaration), amelyben jóllehet deklarálja a menedékhez való jogot, mindazonáltal ennek biztosítását a tagállami szabályozásokra bízza. ${ }^{20} \mathrm{~A}$ szervezet kerüli a menekültkérdés napirendre vételét, mivel ez a tagállamok belügyébe való beavatkozásnak számítana, amit az alapító okirat tilt. ${ }^{21}$ Ez a hozzáállás a Plan of Action for Cooperation on Immigration Matters elnevezésű akciótervből is világosan látszik, mivel az csupán a térség államai közötti gazdasági jellegű migrációt tárgyalja, és a menekült, menedékkérő vagy lakóhelyét kényszerből elhagyó személy fogalma meg sem jelenik a dokumentumban.

Ezekkel együtt is, szemben az ENSZ és szakosított szervezetei részéről érezhető észrevételekkel (és nyomásgyakorlással), a regionális szervezetek nem kifogásolták a thaiföldi menekültjog hiányát, illetve a menekültek emberi jogainak megsértését.

\section{Nemzetközi jogforrások - lehetőség vagy kötelezettség?}

Mivel Thaiföld máig nem ratifikálta a menekültek helyzetére vonatkozó 1951. évi genfi konvenciót, sem annak 1967. évi, a menekültek jogállásáról szóló jegyzőkönyvét, így az ország nem ismeri el a menekültek jogállását, e státuszból fakadó elismerésre, védelemre a kérelmezők nem számíthatnak. Thaiföld az országban lévő, vízum nélkül érkezetteket, vagy a lejárt turistavízummal rendelkezőket túltartózkodottaknak, illegális bevándorlóknak tekinti. Kérdés tehát, hogy mi emelhető ezen alapvető menekültügyi egyezmény, jogintézmény „helyére”, ennek hiányában mi tekinthető az állam által biztosítandó jogi kötelezettségnek. Mielőtt azonban a thai szabályozást részleteznénk, azokat a nemzetközi jogforrásokat tekintjük át, amelyek (akár közvetett módon) hivatkozási alapjai lehetnek a konzuli, diplomáciai és humanitárius munkának, a menekültekkel szemben alkalmazott negatív, jogsértő bánásmóddal szemben. Azokat a nemzetközi emberi jogi és menekültjogi normákat vesszük részletesebben szemügyre, amelyek relevánsak lehetnek a Thaiföld területén tartózkodó menedékkérők, menekültek vonatkozásában azon okból, mert Thaiföld részese az adott nemzetközi egyezménynek.

18 Asian-African Legal Consultative Organization: „Final text of AALC's 1966 Bangkok Principles on Status and Treatment of Refugees" as adopted on 24 June 2001 at the AACLO'S 40th session, New Delhi (2001).

19 Refugee Legal Aid Information for Lawyers Representing Refugees Globally: Refugee protection in the Asia Pacific region (2021).

20 ASEAN: Human Rights Declaration, Article 16 (2012. november 19.).

21 Refugee Legal Aid Information for Lawyers Representing Refugees Globally (2021): i. m. 
Mind közül az első, az ENSZ által 1948-ban elfogadott, 30 alapvető emberi jogot tartalmazó Emberi Jogok Egyetemes Nyilatkozata, a létező legátfogóbb emberi jogi dokumentum. A védett emberi jogok közül témánk szempontjából kiemelhető az élethez, szabadsághoz és biztonsághoz való jog, valamint védelem a kínzás, a kegyetlen, embertelen bánásmód és büntetés ellen. A Nyilatkozat egy ideális állapotot fogalmaz meg, és jóllehet nem kötelező jogi erejű dokumentum, időközben szinte teljes tartalmát olyan kötelező erejű nemzetközi szerződésekbe foglalták, amelyeket Thaiföld is ratifikált. Ilyen például a királyság által 1999-ben elfogadott Gazdasági, Szociális és Kulturális Jogok Nemzetközi Egyezségokmánya (GSZKJNE), valamint az 1996-ban ratifikált Polgári és Politikai Jogok Nemzetközi Egyezségokmánya (PPJNE). A PPJNE az első generációs alapjogokkal foglalkozik, mint az élethez való jog, a szólás- és vallásszabadság, védelem a kínzás, a kegyetlen, embertelen bánásmód és büntetés ellen. A GSZKJNE pedig a második generációs jogokkal, mint jog a munkához, sztrájkhoz, oktatáshoz, szociális biztonsághoz. A PPJNE-ben biztosított alapjogok úgynevezett abszolút jogok, azaz az emberi méltóságból erednek, és ezáltal nem korlátozhatók, míg a GSZKJNE-ben lefektetett jogok biztosítása az állam tevőleges cselekvését igényli, éppen ezért alávethetők különböző korlátozásoknak. ${ }^{22}$

Noha a GSZKJNE 2. cikkének (2) bekezdése rögzíti, hogy:

- „az Egyezségokmányban részes államok kötelezik magukat arra, hogy biztosítják az Egyezségokmányban rögzített jogoknak fajra, színre, nemre, nyelvre, vallásra, politikai vagy bármely más véleményre, nemzeti vagy társadalmi származásra, vagyoni helyzetre, születésre, vagy minden egyéb helyzetre tekintet nélkül való gyakorlását";

- ugyanezen cikk következő (3) bekezdése kimondja, hogy „a fejlődő országok, kellő figyelemmel az emberi jogokra és saját nemzetgazdaságukra, maguk határozhatják meg, hogy milyen mértékben biztosítják az Egyezségokmányban elismert gazdasági jogokat azok számára, akik nem állampolgáraik".

A PPJNE témánk szempontjából releváns rendelkezései:

A 2. cikk (1) szerint

„az Egyezségokmányban részes, valamennyi állam kötelezi magát, tiszteletben tartja és biztosítja a területén tartózkodó és joghatósága alá tartozó minden személy számára az Egyezségokmányban elismert jogokat, minden megkülönböztetés, nevezetesen faj, szín, nem, nyelv, vallás, politikai vagy más vélemény, nemzeti vagy társadalmi származás, vagyoni, születési vagy egyéb helyzet szerinti különbségtétel nélkül”.

22 Halmai Gábor - Tóth Gábor Attila: Emberi jogok. Budapest, Osiris, 2003. 81-86. 
Azaz, a thai kormány ezzel kötelezettséget vállalt, hogy az Egyezségokmányban foglalt jogokat a joghatósága alá tartozó összes személy, azaz az országban bármilyen jogcímen tartózkodó külföldiek tekintetében is alkalmazza.

A 7. cikk szerint „senkit sem lehet kínzásnak, kegyetlen, embertelen, megalázó elbánásnak vagy büntetésnek alávetni. Különösen tilos bárkit szabad hozzájárulása nélkül orvosi vagy tudományos kísérletnek alávetni." Az Emberi Jogi Bizottság értelmezésében kimondta, hogy a rendelkezés célja a személy méltóságának és fizikai, továbbá lelki integritásának védelme. Fontos kiemelni, hogy e jog korlátozhatatlan, azaz nincs olyan körülmény, amely indokolttá tehetné a jog megsértését. ${ }^{23} \mathrm{~A}$ tilalom kiterjed az olyan országokba való visszaküldésre, ahol a személy kínzásnak, kegyetlen, embertelen vagy megalázó elbánásnak vagy büntetésnek lehet alávetve (non-refoulement).

A 9. cikk szerint „senkit sem lehet önkényesen őrizetbe venni vagy letartóztatni”. Az Emberi Jogi Bizottság kommentárjában kitér a nem büncselekmény következtében (például idegenrendészeti okokból) őrizetbe vettek jogaira. Rögzíti, hogy az ilyen őrizetbevétel esetén fokozottan fennállhat a 9. cikk megsértésének gyanúja. Az őrizetbe vett személy esetében azonnali, közvetlen és sürgető veszélyhelyzetnek kell fennállnia ahhoz, hogy a jogkorlátozás indokolt legyen. Az intézkedést csak akkor lehet alkalmazni, amennyiben alternatív lehetőségek nem vezetnének eredményre, és akkor is csak bírósági kontroll mellett és a lehető legrövidebb ideig. ${ }^{24}$

\section{A 10. cikk szerint}

„1. A szabadságuktól megfosztott személyekkel emberségesen és az emberi személyiség veleszületett méltóságának tiszteletben tartásával kell bánni. 2. a) A vádlottakat, amennyiben nem állnak fenn kivételes körülmények, el kell különíteni az elítéltektől és olyan külön elbánásban kell részesíteni őket, amely megfelel annak a helyzetnek, hogy nincsenek elítélve; b) a fiatalkorú vádlottakat a felnőttektől el kell különíteni és ügyükben a lehető legrövidebb időn belül dönteni kell.”

Az Emberi Jogi Bizottság ezt a cikket értelmezve egyértelművé tette, hogy az mindenfajta elzárásra kiterjed. A testület azt is kimondta, hogy az emberi méltóságot a fogvatartottak esetében ugyanúgy tiszteletben kell tartani, mint a szabad személyek esetében, így ők - a szabadságuktól megfosztást kivéve - az összes, a PPJNE-ben biztosított jogot élvezhetik. Fontos kiemelni az értelmezésből, hogy itt az EJP szerint egy

23 UNHRC: CCPR General Comment No. 20: Article 7 (Prohibition of Torture, or Other Cruel, Inhuman or Degrading Treatment or Punishment) (1992. március 10.).

24 UNHRC: General comment No. 35, Article 9 (Liberty and security of person) (2014. december 16.). 
„minimumsztenderdről” van szó, így a jog biztosítása nem függhet az adott ország anyagi lehetőségeitől..$^{25}$

\section{A 24. cikk szerint}

„1. Minden gyermeknek fajra, színre, nemre, nyelvre, vallásra, nemzeti vagy társadalmi eredetre, vagyonra, vagy születésre való tekintet nélkül joga van arra a védelemre, amelyet őt kiskorú állapota folytán a családja, a társadalom és az állam részéről megilleti. 2. Minden gyermeket közvetlenül születése után anyakönyvezni kell és nevet kell neki adni. 3. Minden gyermeknek joga van arra, hogy állampolgárságot szerezzen".

Itt az EJP fontosnak tartotta kiemelni, hogy a gyermekeket a 24. cikkben nevesített jogokon kívül az Egyezményben lefektetett összes jog ugyanolyan mértékben megilleti, mint a felnőtteket, és hogy a jogok biztosítása az államok tevőleges szabályozását igényli. ${ }^{26}$

Szintén fontos és releváns az ENSZ 1984-ben elfogadott Kínzás elleni Egyezménye, amelyet Thaiföld 2007-ben ratifikált. Az Egyezménnyel egyetértő országok elismerik, hogy a kínzást kötelesek megakadályozni és az elkövetőit felelősségre vonni, összhangban az Egyezmény meghatározásaival. Szintén kötelesek azonban megakadályozni és büntetni más kegyetlen, embertelen vagy megalázó bánásmódokat vagy büntetéseket abban az esetben, ha ezt hivatalos személyek vagy más hivatali minőségben eljáró személyek követik el, az ő felhatalmazásuk vagy felbujtásuk, egyetértésük vagy hallgatólagos beleegyezésük mellett.

Az Egyezmény tagjai kötelesek hatékony törvényhozási, adminisztratív, bírói és egyéb eszközökkel megakadályozni és megelőzni a kínzás alkalmazását a fennhatóságuk alatt lévő területeken.

Az Egyezmény 3. cikke szerint:

„1. Egyetlen részes állam sem köteles kiutasítani, hazatoloncolni vagy kiadni valakit egy másik olyan államnak, ahol nyomós okoknál fogva tartani lehet attól a veszélytől, hogy az illető személyt megkínozzák. 2. Annak eldöntésére, hogy fennállnak-e ilyen okok, az illetékes hatóságoknak figyelembe kell venniük az ügyre vonatkozó minden szempontot, ideértve az adott esetben azt is, hogy az érintett államban rendszeresen, súlyosan, nyilvánvalóan vagy tömeges méretekben megsértik az emberi jogokat".

25 UNHRC: CCPR General Comment No. 21: Article 10 (Humane Treatment of Persons Deprived of Their Liberty) (1992. április 10.).

26 UNHRC: CCPR General Comment No. 17: Article 24 (Rights of the Child) (1989. április 7.). 
Ez a már az Egyezségokmány esetében is tárgyalt non-refoulement alapelv érvényesítése, azaz az Egyezmény megerősíti, hogy a személy nem toloncolható haza abba az országba, ahol a fenti veszély fenyegetné.

1989. november 20-án az ENSZ Közgyűlése elfogadta a Gyermek Jogairól szóló Egyezményt, ${ }^{27}$ és 1990 . január 26-án megnyitotta aláírásra. Az egyezmény súlyát és fontosságát jelzi, hogy még aznap 61 ország írta alá. Az egyezmény rekord gyorsasággal, 1990. szeptember 2-án, egy hónappal a huszadik ratifikáció után lépett hatályba. Azóta - az Egyesült Államok, Szomália és Dél-Szudán kivételével - a világ összes országa, így Thaiföld is, ratifikálta. Az Egyezmény 2. cikke rögzíti, hogy az Egyezményben biztosított jogok minden gyermeket megilletnek, mindenfajta korlátozás (nem, anyagi helyzet, vallás stb.) nélkül.

A 3. cikk szerint a döntéshozóknak minden esetben a gyermek legfőbb érdekét kell figyelembe vennie (best interests of the child).

A Gyermek Jogainak Bizottsága az egyezményt értelmezve kimondta, hogy

„az egyezményben biztosított jogok gyakorlása nem korlátozható azon gyermekekre, akik a részes államok polgárai, és amennyiben annak ellenkezőjét az egyezmény kifejezetten nem állítja, minden gyermek számára elérhetőnek kell lennie, beleértve a menedékkérőket, menekülteket és migráns gyermekeket, függetlenül nemzetiségüktől, migrációs helyzetüktől vagy hontalanságuktól”."28

Így, az összes olyan cikk, amelynek tekintetében az adott állam nem élt fenntartással, kiterjed a joghatóság alatt álló menedékkérő, menekült vagy migráns gyermekekre is. ${ }^{29}$ Ezek az abszolút jogok többek között a következők: az élethez való jog, a születést követő anyakönyvezéshez való jog, a tulajdonhoz való jog, az egészségügyi ellátáshoz való jog, a védelem a gazdasági és szexuális kizsákmányolástól, valamint a kínzástól, halálbüntetéstől, életfogytig tartó börtönbüntetéstől és önkényes fogvatartástól való mentesség. A Bizottság a non-refoulement elvet is értelmezte olyképpen, hogy az elv alkalmazása semmi esetre sem korlátozható (by no means limited to) a kínzás, kegyetlen, embertelen vagy megalázó büntetés eseteire, hanem minden olyan esetben alkalmazni kell azt, ahol alapos okkal lehet feltételezni, hogy a személyt visszafordíthatatlan kár (irreparable harm) éri visszatoloncolása esetén. ${ }^{30}$

Az itt felsorolt nemzetközi jogi vonatkozások ratifikációjuk okán Thaiföld számára is relevánsak. Mégis, az országban tartózkodó menekültet napi szinten éri olyan sére-

27 UNICEF: Convention ont he Rights of the Child. General Assembly resolution 44/25 (1989. november 20.).

28 UNCRC: General comment No. 6 (2005): Treatment of Unaccompanied and Separated Children Outside their Country of Origin (2005. szeptember 1.).

29 Ian Werrett: Protecting Vulnerable Children in Thailand. Thailand Law Journal, 17. (2014), 1.

30 UNCRC (2005): i. m. art. 27. 
lem (visszaküldés tilalma, gyermekek letartóztatása, kegyetlen bánásmód stb.), amely az itt felsorolt egyezmények, jogi dokumentumok vonatkozásában elfogadhatatlan.

\section{Menekültként Thaiföldön: elmélet és gyakorlat}

Thaiföld alkotmányos monarchia, ahol az államfő a király, a miniszterelnök (a hadsereg föparancsnoka) pedig a végrehajtó hatalom feje. A kétkamarás parlament a törvényhozó hatalmat gyakorolja. Az állam irányításában de facto szerepe van a hadseregnek is, amely időről időre katonai puccs révén szerez érvényt jogainak. A thai jogrendszer legfőbb jogforrása az alkotmány, amelyet legutóbb 2017-ben módosítottak és fogadtak el. A nemzetközi szerződéseket a király köti, azonban a legtöbb esetben ez a thai parlament két házának jóváhagyásához van kötve. ${ }^{31}$ Ilyen példa, ha egy nemzetközi szerződést kell implementálni a thai jogrendszerbe. A thai jogi hagyomány az úgynevezett dualista megközelítést követi, azaz a nemzetközi jog szabályait az állam külön jogalkotási aktus révén építi be saját belső jogába (transzformáció), hogy azok a belső jogban is érvényesülhessenek. A nemzetközi emberi jogi egyezményekben vállalt kötelezettségek - jóllehet erről az alkotmány nem rendelkezik - jellegüknél fogva transzformáció nélkül is érvényesíthetők, ahogy erre a thai bíróságok több döntésükben is utaltak. ${ }^{32}$

A thaiföldi adminisztráció a menekültkérdéshez, annak jogi szabályozásához, az emberi jogokhoz mint nyugati „találmányhoz” való óvatos-negatív hozzáállásának okait tehát az átélt történelmi élményekben, emlékekben kereshetjük. A bevándorlással kapcsolatos legfontosabb, szinte egyetlen dokumentum az 1979-ben elfogadott, máig hatályban lévő bevándorlási törvény. ${ }^{33}$ Ezt az 1970-es évek második felében a vietnámi hadsereg és a Kambodzsát kormányzó vörös khmerek harcainak következtében Thaiföldre menekült sok százezer kambodzsai menekült okozta humanitárius válság hívta életre. Noha Thaiföld a kambodzsai menekültek egy részének ideiglenes védelmet biztosított, a törvény nem tett különbséget menekült és illegális migráns között, így mindenki, aki a thai kormány hozzájárulása nélkül lépett az ország területére (vagy már ott tartózkodott), illegális migránsnak számított és kitoloncolásnak volt alávethető. Jóllehet az ENSZ Menekültügyi Főbiztossága is ekkor létesített irodát az országban, mint azt Sara Ellen Davies megállapítja, 1980 januárjára az addigiakhoz képest is keményebbre fordult a thai menekültpolitika a szomszédos országok konszolidációjának következtében. ${ }^{34} \mathrm{Ez}$ a hozzáállás éles ellentétben áll a liberálisnak nevezhető thai vízumpolitikával, hiszen nehezen érthető, hogy a thai kormány, miközben könyörtelenül lecsap az országban illegálisan tartózkodókra, az országba való beutazás szabályait nem szigorítja. Az ellentmondás valószínűleg abban oldható fel,

31 Thailand's Constitution of 2017. 178. cikk.

32 Withit Mantāphọ̄n: The Core Human Rights Treaties and Thailand. Brill, 2016.

33 Office of the Council of State: Immigration Act, B.E. 2522. 1979.

34 Sara Ellen Davies: Legitimising Rejection: International Refugee Law in Southeast Asia. After the 1979 Conference: the Early 1980s. Leiden, Brill Nijhoff, 2007. 
hogy Thaiföld egyszerre kívánja korlátozni és az olcsó munkaerő folyamatos kereslete miatt ösztönözni is az illegális bevándorlást. ${ }^{35}$

\section{Városi menekültek Bangkokban}

A városi menekültek olyan személyek, akik a hivatalos, formális kereteken kívül, jellemzően a nagyvárosok nyújtotta árnyékvilágban, bújkálva élnek. Státusszal többnyire nem rendelkeznek, azonban, ha tartózkodásuk legális is, munkát akkor se vállalhatnának, ellátásra nem jogosultak, társadalombiztosítással nem rendelkeznek, adózni nem tudnak. Ök döntően a feketegazdaságban elhelyezkedve szereznek jövedelmet. Életük azonban igen kockázatos: nem csupán egzisztenciális létbizonytalanságban és félelemben élnek, de ex lex helyzetükből adódóan olyan veszélyeknek vannak kitéve, mint a letartóztatás, a kizsákmányolás, a bántalmazás vagy az abúzus. Különösen igaz ez a nem befogadó környezetre, kiváltképp azon társadalmakra, amelyekben a jogcím nélkül az országban tartózkodó személyek rendszerszintủ üldöztetésnek vannak kitéve. Thaiföldön e városi menekültek, a helyi jog alapján tehát illegális bevándorlók, legjellemzőbben Bangkokban élnek. Az esetek döntő többségében kérelmezték a UNHCR „nemzetközi védelemét”, amely azt menekültügyi eljárás keretében saját hatáskörben vizsgálta. Amennyiben valakit (UNHCR-terminussal) menekültként ismernek el, őt (mivel thaiföldi jogszerü tartózkodása így sem biztosított) egy befogadó harmadik országba való áttelepítésére terjesztik fel. Az eljárás mindazonáltal roppant hosszadalmas, aminek következtében - a turistavízumuk lejártát követöen - a thai hatóságok azokkal szemben is idegenrendészeti eljárást folytatnak le, akik regisztráltak a UNHCR-nél és úgynevezett „ENSZ-kártyával” rendelkeznek. ${ }^{36} \mathrm{~A}$ biztonságos harmadik országba áttelepítést azonban csak a menedékkérők elenyésző részének tudják a nemzetközi szervezetek biztosítani, de a kérelmek jelentős részét nem bizonyítják, így nem is fogadják el a UNHCR szakemberei. E városi menekülteknek Thaiföldre való belépésük 61. napjától (tehát turistavízumuk lejártát követően) túltartózkodási díjat kellene fizetni, 500 Baht-ot naponta, 40 napot meghaladó tartózkodás esetén 20000 Baht-ot, egy összegben. Persze tartózkodásuk ettől még nem lesz jogszerủ, de alkalmassá válhatnak a tolonceljárás lefolytatására és az ország elhagyására, amelyet követően Thaiföldre vissza nem jöhetnének.

\section{Emberi jogok és az idegenrendészeti eljárás Thaiföldön}

A menedékkérők és menekültek thaiföldi tartózkodását a jelenleg is hatályban lévő 1979-es bevándorlási törvény alapján bírálják el a hatóságok. A jogszabály több szempontból sem áll összhangban a vonatkozó emberi jogi normákkal. A hatósági személyek saját mérlegelésük alapján letartóztathatják a külföldieket, valamint nincs

35 Prem Kumar Rajaram - Carl Grundy-Warr: The Irregular Migrant as Homo Sacer: Migration and Detention in Australia, Malaysia and Thailand. International Migration, 42. (2004), 1. 33-64. 
rögzítve az idegenrendészeti őrizetben töltött idő maximuma sem. ${ }^{37} \mathrm{~A}$ felmerülő költségeket pedig az ügyfeleknek saját maguknak kell kifizetniük. ${ }^{38} \mathrm{E}$ törvény kriminalizálja a jogszerütlen tartózkodást, így az országban illegálisan tartózkodók legfeljebb két év börtönbüntetéssel és 20000 thai Baht pénzbüntetéssel sújtandók. ${ }^{39} \mathrm{~A}$ jogszabály alapján a hatóságok rendszeresen vesznek őrizetbe külföldieket, köztük gyermekeket is, akiket aztán fogva tartanak és esetenként kitoloncolnak olyan származási országokba, ahol az adott személyek veszélyeztetve vannak. ${ }^{40} \mathrm{~A}$ törvény tehát nem érvényesíti a non-refoulement elvet. ${ }^{41}$

Megállapítható, hogy a jelenleg érvényben lévő bevándorlási törvény több ponton is sérti a Thaiföld által is elfogadott nemzetközi emberi jogi normákat, így a PPJNE önkényes letartóztatásra vonatkozó 9. cikkét és a non-refoulement elvet. A szintén a PPJNE 9. cikkben rögzített alternatívák a menekültek fogvatartására sem állnak rendelkezésre. A hatósági jogalkalmazás ezen túl további problémákat is felvet: elsősorban az IDC-k túlzsúfoltsága, fizikai bántalmazás, a fogvatartottak háztartási láncokkal való falhoz rögzítése, az alapvető szolgáltatásokhoz, egészségügyi ellátáshoz való hozzáférés hiánya, valamint a kiskorúak fogvatartása a legkardinálisabb problémák. ${ }^{42}$ 2018-ban a Human Rights Watch nevü nemzetközi jogvédő szervezet nyílt levélben fordult a thai miniszterelnökhöz, kérve őt, hogy hagyjanak fel az ENSZregisztrációval rendelkező pakisztáni keresztény és ahmadi muszlim menedékkérők őrizetbe vételével és deportálásával. Levelükben hivatkoztak Thaiföld kötelezettségeire a Kínzás elleni Egyezmény rendelkezéseinek tekintetében, azon belül is elsősorban a non-refoulement elvére, figyelemmel a Pakisztánban a keresztények ellen rendszeresen elkövetett atrocitásokra, továbbá a Gyermek Jogairól Szóló Egyezmény azon cikkére, amely alapján a gyermek csak akkor szakítható el a szüleitől, amennyiben egy bírósági kontroll alatt működő hatóság úgy ítéli meg, hogy ez tekinthető a gyermek legfőbb érdekének. ${ }^{43} \mathrm{~A}$ jogvédő szervezetek jelezték, hogy a non-refoulement elv megsértésén túlmenően, az idegenrendészeti őrizetben megalázó, embertelen állapotok uralkodnak, ${ }^{44}$ sőt gyermekeket is tartanak fogva ezeken a helyeken, nyilvánvalóan megsértve ezzel a fent tárgyalt nemzetközi egyezményeket. ${ }^{45}$

A thai kormány mindezidáig nem szánta rá magát sem a szóban forgó jogszabály, sem a gyakorlat megváltoztatására, noha az UNHCR és a Save the Children jogvédő szervezet több alternatív szabályozási javaslatot is kidolgozott az elmúlt években. ${ }^{46} \mathrm{Az}$ emberi jogok sérelmére vonatkozó, elsősorban a thai kormány letartóztatási

37 Office of the Council of State (1979): i. m. 19. és 20. cikk.

38 Office of the Council of State (1979): i. m. 21. cikk.

39 Office of the Council of State (1979): i. m. 81. cikk.

40 Amnesty International (2017): i. m.; IOM UN Migration (2019): i. m. 21.

41 Office of the Council of State (1979): i. m. 54. cikk.

42 Global Detention Project: Thailand (2021).

43 Human Rights Watch: Re: Pakistani asylum seekers in Thailand (2018. november 6.).

44 UCA News (2020): i. m.

45 Human Rights Watch: Two years with No Moon. Immigration Detention of Children in Thailand (2014. szeptemer 1.).

46 Jasmine Chia: Detention centres stuck in past century. Bangkok Post, 2018. február 18. 
gyakorlatát érintő kritikákra válaszul 2019 januárjában több thai kormányzati szerv egyetértési megállapodást kötött. ${ }^{47} \mathrm{~A}$ dokumentum értelmében az aláíró kormányzati szervek kötelezték magukat arra, hogy gyermekek fogvatartására csak a legvégső esetben kerülhet sor, és ez esetben is a lehető legrövidebb ideig. Amennyiben erre mégis sor kerülne, a gyermekeket a felnőttektől elkülönítve, külön menhelyeken kell őrizni. Bár a megállapodás aláírása mindenképpen fejlődést jelent a korábbi állapotokhoz képest, nem teremt megoldást a családok szétszakításának problémájára, és nem szünteti meg azt a gyakorlatot, hogy a fogva tartott édesanyák 50000 thai Baht óvadék kifizetését követően találkozhatnak csak a felnőttektől külön őrzött gyermekeikkel.

\section{Az ENSZ lehetséges szerepe a thaiföldi emberi jogi helyzet ellenőrzésében}

Thaiföld tehát nem részese a menekültügyi egyezménynek, így nem is folytat le menekülteljárást a területén tartózkodó, arra rászoruló külföldiek esetében. Ezáltal emberi jogi védelem „lép” a menekültügyi jogszabályok hiánya teremtette ürbe, és a jogvédelem szinte egyedüli, az adott államon számonkérhető formájává válik. ${ }^{48}$

Amint ezt korábban részletesen kifejtettük, Thaiföld a PPJNE-t 1996-ban, míg a GSZKJNE-t 1999-ben ratifikálta. Ezeken túl a királyság az alábbi egyezményeknek is részes állama, így közvetett módon vonatkoznának rá az ezekben foglaltak:

- az ENSZ a kínzás és más kegyetlen vagy megalázó bánásmódok elleni nemzetközi egyezménye;

- a nőkkel szembeni megkülönböztetés minden formájának felszámolásáról szóló nemzetközi egyezmény;

- a faji megkülönböztetés valamennyi formájának kiküszöböléséről szóló nemzetközi egyezmény;

- a gyermek jogairól szóló egyezmény;

- valamint a fogyatékos személyek jogairól szóló egyezmény.

Ennek következtében az ENSZ, illetve annak bizottságai időszakonként felülvizsgálják a thaiföldi emberi jogi helyzetet, és ajánlásokat, észrevételeket fogalmaznak meg azzal kapcsolatban. ${ }^{49} \mathrm{~A}$ következőkben érintőlegesen azokat az észrevételeket emeljük ki, amelyeket kifejezetten a menedékkérőket, menekülteket, migránsokat érintően fogalmaztak meg.

Az ENSZ Közgyülése által létrehozott Emberi Jogi Tanács a Nyilatkozat érvényesülésének vizsgálatára és az emberi jogok betartatásának ellenőrzéseként 2006-ban

47 UNHCR: UNHCR welcomes Royal Thai Government's commitment to release of detained children in Thailand (2019. január 21.).

48 Azért csak szinte, mert az ENSZ a Menekültügyi Egyezményt el nem fogadó államokban tartózkodó menekültnek minősülő személyek számára is biztosít védelmet (lásd II/a), ez a védelem azonban - mint azt kifejtettük - nem óv meg az emberi jogi jogsértésektől.

UNHR: Thailand (é. n.). 
indította el az úgynevezett egyetemes időszakos emberi jogi felülvizsgálati eljárást (Universal Periodic Review, UPR-t), az ENSZ minden tagállamát - tehát a világ szinte minden országát - időről időre jelentéstételre kötelező ellenőrzési folyamatot. A UPR egyedülálló felülvizsgálati mechanizmus, amely lehetőséget ad az adott állam számára (minden negyedik évben), hogy bemutassa, milyen lépéseket tett az országa emberi jogi helyzetének javítása és kötelezettségének teljesítése érdekében. A UPR az államok más szerződésein alapuló ellenőrzési kötelezettségeit egészíti ki, attól függetlenül, hogy az ENSZ-tagállam részese-e más emberi jogi tárgyú szerződésnek, avagy sem. 2016-ban a Thaiföld emberi jogi helyzetét áttekintő felülvizsgálat során a többi ENSZ-tagállam által tett 249 emberi jogi ajánlás közül a thai kormány 189-et fogadott el, köztük azt, hogy megoldásokat dolgoz ki a fogvatartási helyek (IDC-k) túlzsúfoltságának csökkentésére, és javítja a sérülékeny csoportok, így a menekültek oktatáshoz, egészségügyi és szociális ellátásokhoz való hozzáférését. ${ }^{50}$ Mindazonáltal nem fogadta el, hogy csatlakozzon a menekültügyi egyezményhez, és felhagyjon a menedékkérők őrizetbe vételével és deportálásával.

A PPJNE 28. cikke rendelkezett az ENSZ Emberi Jogi Bizottságának (Human Rights Commitee, EJP) megalakításáról. Ez a 18 emberi jogi szakértőből álló bizottság felelös annak biztosításáért, hogy a PPJNE minden aláírója eleget tegyen a benne foglaltaknak. A bizottság megvizsgálja az országok által ötévente benyújtott jelentéseket, hogy biztosítsa a PPJNE betartását a részükről, és határozatot bocsát ki az ország által nyújtott teljesítményről. Az EJP 2017-ben kiadott, a thai országjelentésre tett záró észrevételeiben felhívta Thaiföldet, hogy tartózkodjon a menedékkérők fogvatartásától, dolgozzon ki ennek helyettesítésére alternatív megoldásokat, és amennyiben a fogvatartás nem kerülhető el, az olyan egyéni körülményeken alapuljon, amelyek indokoltak, arányosak és szükségesek, a fogvatartás indokoltságát időközönként felülvizsgálják, továbbá legyen bírósági kontroll. Felszólításukban kitértek arra is, hogy a gyerekek szabadságát csak rendkívüli esetekben vonják meg, a lehető legrövidebb időre, és legyenek elkülönítve olyan felnőttektől, akik nem a családtagjaik. ${ }^{51}$

A Gazdasági, Szociális és Kulturális Jogok Bizottság (GSZKJB) felügyeli a GSZKJNE rendelkezéseinek betartását. A GSZKJB a 2015-ös thai országjelentésre tett záró észrevételeiben kiemelte, hogy - miközben értékeli, hogy Thaiföld nagy létszámban fogad menekülteket a szomszédos országokból és együttműködik a UNHCR-vel - aggodalmát fejezi ki a menedékkérők, menekültek és jogaikat védő nemzeti keretrendszer, valamint a menekültügyi eljárás hiánya miatt. A GSZKJB megjegyezte, hogy az gátolja a gazdasági, szociális és kulturális jogok teljes körű érvényesülését. A testület ezért felszólítja Thaiföldet, hogy jogi keretrendszerét hozza összhangba nemzetközi jogi

50 Universal Periodic Review: 2RP: Responses to Recommendations and Voluntary Pledges. Thailand (2016. május 11.).

51 UNHRC: Concluding observations on the second periodic report of Thailand (2017. április 25.) 30. cikk. 
kötelezettségeivel, és vizsgálja felül a negatív álláspontját a menekültügyi egyezmény és annak jegyzőkönyve elfogadásával kapcsolatban. ${ }^{52}$

Thaiföld 2007-ben fogadta el a Kínzás elleni Egyezményt. Az egyezmény szintén gondoskodik egy független, nemzetközi testület, a Kínzás elleni Bizottság (KEB) létrehozásáról, amely egyrészt figyelemmel kíséri és támogatja az egyezmény betartását, másrészt kivizsgálja a kínzással kapcsolatos vádakat az érintett államokkal együttmüködésben. A KEB 2014-es thai országjelentésre tett záró észrevételeiben aggodalmát fejezte ki a hosszú és sok esetben meghatározhatatlan idejű idegenrendészeti fogvatartás vonatkozásában, továbbá kifogásolta az elzárásokról szóló ítéletek független és rendszerszintű kontrolljának és az elzárás helyett alkalmazott egyéb intézkedéseknek a hiányát. Felszólítja Thaiföldet, hogy vizsgálja felül a menedékkérőkkel szemben alkalmazott elzárások rendszerét, és dolgozzon ki alternatívákat arra. Az államnak fel kell hagynia a menedékkérők és migránsok határozatlan idejű elzárásának gyakorlatával, és garantálnia kell részükre a független, minőségi és ingyenes jogi tanácsadást és képviseletet annak érdekében, hogy a nemzetközi védelemre szoruló esetek felismerhetők legyenek, és elkerülhető legyen a kitoloncolás. ${ }^{53}$

Thaiföld 1992-ben csatlakozott a gyermek jogairól szóló egyezményhez, mindazonáltal a menekült gyermekek jogainak biztosításáról szóló 22. cikk ${ }^{54}$ tekintetében fenntartással élt, amennyiben rögzítette, hogy „a fenti cikk alkalmazása a nemzeti jogszabályoknak, egyéb rendelkezéseknek és a hazai gyakorlatnak van alárendelve". A gyermek jogairól szóló nemzetközi egyezmény 44. cikke alapján minden, az egyezményben részes államnak ötévenként jelentésben kell beszámolnia arról, hogy milyen intézkedéseket tett az egyezmény rendelkezéseinek végrehajtása érdekében. Az egyezmény 44. cikke azt is előírja, hogy az országjelentéseket minél szélesebb körben bárki által hozzáférhetővé kell tenni. A jelentéseket a Gyermek Jogainak Bizottsága (GYJB), egy független szakértőkből álló nemzetközi testület vizsgálja meg, és az adott ország civil szervezeteinek, majd kormányának meghallgatását követően ajánlásokat tesz. A GYJB a 2012-es thaiföldi országjelentésre tett záró észrevételeiben megfogalmazott ajánlásában a gyermek jogairól szóló egyezmény 22. cikkével kapcsolatban tett fenntartás visszavonására hívta fel a thai kormányzatot, egyben arra, hogy tegye meg az összes szükséges lépést a menedékkérő és menekült gyermekek jogainak védelmében. ${ }^{55} \mathrm{~A}$ Bizottság aggodalmát fejezte ki egyrészről a menekültek részére kijelölt táborokban uralkodó körülmények miatt, másrészt amiatt, hogy a táborokon kívül, a vá-

52 UNHRC (2017): i. m. 15. cikk.

53 UN CAT Committee: Concluding observations on the initial report of Thailand (2014. június 20.) 21. cikk.

54 Az Egyezményben részes államok megteszik a megfelelő intézkedéseket, hogy az a gyermek, aki akár egymagában, akár apjával és anyjával vagy bármely más személlyel együtt az erre vonatkozó nemzetközi vagy hazai szabályok és eljárások értelmében menekült helyzetének elismerését kéri, vagy menekültnek tekintendő, megkapja az Egyezményben és más emberi jogokkal kapcsolatos vagy humanitárius jellegű egyéb nemzetközi okmányokban, amelyekben az említett államok részesek, elismert jogok élvezetéhez szükséges védelmet és humanitárius támogatást. 
rosokban tartózkodó menedékkérők és menekültek illegális migránsnak minősülnek, és ezért letartóztatásnak, elzárásnak és kitoloncolásnak vannak kitéve. Ajánlásában felhívta Thaiföldet, hogy a menedékkérőket és a menekülteket státuszuknak megfelelően kezelje, és ne toloncolja ki őket olyan országba, ahol az életük veszélyben foroghat. Bátorítják a kormányzatot, hogy ennek érdekében kérje a UNHCR technikai segítségét. A Bizottság felhívta a kormányzatot, hogy ratifikálja a menekültügyi egyezményt és annak jegyzőkönyvét, és hozzon létre nemzeti jogi és intézményi keretrendszert a menekültek védelmére. ${ }^{56}$

\section{A bangkoki realitás - aggályos lépések az ENSZ Menekültügyi Főbiztossága részéről}

A Menekültügyi Főbiztossága az 1970-es évek indokínai menekültválsága óta van jelen az országban. Évente körülbelül 20 millió amerikai dollárt fordít a helyi segélymunkára, és emberek ezreinek nyújt valamilyen támogatást. ${ }^{57}$ És miközben elismeri, hogy a menekültek thaiföldi megítélése nincs összhangban sem a nemzetközi normákkal, sem a sérülékeny és kárvallott személyek valós igényeivel, saját helyi gyakorlatával kapcsolatban több aggály is megfogalmazható. A UNHCR helyi irodája személyes felkeresés, kezdeményezés alapján folytatja le azt a meghallgatást, amelynek eredményeképpen dönt a kérelmekről és (pozitív döntés esetén) müködik közre a kérelmező repatriációjában, azaz egy harmadik, befogadó országba való áttelepítésében. Jóllehet, ez a folyamat éveket vesz igénybe, és szinte nem is ismert ezzel ellentétes, gyorsabb lefutási idejü eset. Az első gyakori probléma már az interjúk során felmerül, ugyanis sok üldözött keresztény - akiket például Pakisztánban úgynevezett blaszfémiavád alapján ítéltek el ügyében olyan muszlim tolmács fordít, akivel szemben az ügyfél részéről nem csupán bizalmatlanság áll fenn, de számos esetben kimutatható volt, hogy nem megfelelően vagy torzítva adta át az elmondottakat. A vallási, etnikai, kulturális gyökerủ üldözéstörténeteket a UNHCR gyakran nem tekinti bizonyíthatónak, megalapozottnak, így ezekben az esetekben elutasító, úgynevezett negatív refugee status determination (RSD-) ítéleteket hoz. Számos kérelmező fordul az iroda genfi központjához felülvizsgálatért: minden általunk ismert ilyen esetet visszaküldték Bangkokba, helyi döntésre.

A thaiföldi UNHCR-iroda egyik legproblematikusabb gyakorlata azonban talán mégsem az interjúkkal kapcsolatos. Azt a személyt, aki menekültkénti elismerést, védelmet kér, a bangkoki központ regisztrálja rendszerébe. Ezt követően egy fényképes, személyes adatokat tartalmazó igazolványt állítanak ki részére. A kártyán szereplő szöveg szerint a kártya birtokosa a UNHCR által regisztrált személy, akit akarata ellenére származási országába visszaküldeni nem lehet. A thai rendőrség és idegenrendészet szolgálatteljesítői (a thai törvények értelmében) azonban pontosan tudják, hogy ennek a kártyának nincs semmilyen helyi, jogi ereje. Ellentétben a menekültekkel, akik igazoltatás

56 UNCRC (2012): i. m. 70.

57 UNHCR Executive Committee of the High Commissioner's Programme: Update on budgets and funding (2020-2021) (2021. március 4.). 
során nyugodtan mutatják fel igazolványukat. Személyes találkozások, interjúk során tapasztaltuk (elmondások, fizikai bántalmazási jelek, kórházi zárójelentések alapján), hogy a UNHCR-kártya felmutatásával számos esetben csak annyit „bizonyít” az illeto, hogy ellene a rendőr „büntetlen” erőszakot követhet el: ugyanis olyan személy, aki helyi jogokkal nem rendelkezik, illegális tartózkodó. Több száz olyan eset ismert, amely során rendőrök az utcán, gépkocsiban abuzáltak menekült nőket. Mi több, ismertek azok a csoportok, akik éppen ezért a UNHCR-kártyával rendelkezőkre „vadásznak”.

\section{Egy lépés előre?}

Az ENSZ 2016-os New York-i menekültügyi fórumát követően Prayut Chan-o-cha thai miniszterelnök ígéretet tett egy menekültügyi mechanizmus létrehozására, amelynek első lépéseként egy 2017-es kormányhatározattal létrehozták a Committee for the Management of Undocumented Migrants and Refugees nevü bizottságot, ${ }^{58}$ és ígéretet tettek a National Screening Mechanism elnevezésủ menekültügyi mechanizmus bevezetésére is. ${ }^{59}$ Magát a mechanizmust kormányhatározattal 2019 végén fogadták el, azonban a rendelkezés tartalmi elemei közül több homályos, illetve a gyakorlati alkalmazás próbájára vár. A thai jogalkotók továbbra is kerülik a menekült szó használatát, a jogszabály e helyett védendő személyekről (protected person) beszél. Azt azonban, hogy ki tartozik ebbe a körbe, azt nem objektív kritériumok, hanem a bizottság tagjai döntik el. Egyelöre az sem tisztázott, hogy az új mechanizmus milyen viszonyban áll majd a UNHCR által biztosított nemzetközi védelemmel, illetve, hogy e védendő személyek vonatkozásában Thaiföld alkalmazni fogja-e a non-refoulementre vonatkozó nemzetközi emberi jogi kötelezettségeit. ${ }^{60}$

\section{Zárógondolatok}

Thaiföld, hasonlóan a régió több országához, politikai síkon elköteleződött a menekültek védelme mellett, a jogi kötelezettségvállalásokat azonban továbbra is kerülni igyekszik. A migráció kérdését alapvetően idegenrendészeti, illetve gazdasági kérdésként szemléli, és nem tesz különbséget menekültek és egyéb okokból az országban tartózkodó migránsok között. E közben a thai kormány továbbra is a térség legliberálisabb vízumpolitikáját folytatja, abból a megfontolásból, hogy támogassa a turizmust és segítse a munkaerőpiac igényeinek kielégítését. Ebben a taszító és vonzó hozzáállásban megfigyelhető a nyugatitól lényegesen eltérő „ázsiai értékeken” alapuló hagyomány és jogfelfogás.

58 Committee for the Management of Undocumented Migrants and Refugees: Cabinet Resolution 10/01, B.E. 2560 határozat.

59 Jittawadee Chotinukul: Thailand and the National Screening Mechanism: A Step Forward for Refugee Protection? The Global Migration Research Paper Series 25, 2020.

60 Waritsara Rungthong: Thailand's National Screening Mechanism: Key Issues. Opinion Juris, 2020. január 28. 
Munkánkban bemutattuk, hogy az ENSZ menekültügyi egyezményéhez nem csatlakozott országban biztosított nemzetközi védelem nem képes megóvni a menedékkérőket attól, hogy a hatóságok illegális bevándorlóként kezeljék és kriminalizálják e személyeket. Az ENSZ rendszere mindeközben túlterhelt, lassú, és csupán a menedékkérők nagyon kis részének áttelepítése lehetséges, őket befogadni szándékozó harmadik országok híján. A jogvédelem kikényszeríthetősége azonban továbbra is problémás, ahogyan azt Szakáli Máté is megállapítja:

„[A]z egyes államok szuverenitása ugyanis az emberi jogok felett áll - a népirtás esetének kivételével -, így azok megváltoztathatják hozzáálásukat az emberi jogokat illetően, és felmondhatják egyezményeiket. A nemzetközileg elismert emberi jogokat szisztematikusan megsértő országok nem veszítik el nemzetközi jogalanyiságukat a jogsértések következtében, de megfigyelhető, hogy az emberi jogok tiszteletben tartása a politikai legitimáció és a nemzetközi beágyazottság egyik feltételévé vált.” ${ }^{61}$

Kiindulási alapként tett megállapításunk, azaz a menekültek sérülékeny, jogilag rendezetlen helyzete Thaiföldön továbbra is fennáll. A problémákért ugyan joggal kárhoztatjuk a thaiföldi adminisztráció negatív hozzáállását, azonban azt is meg kell jegyeznünk, hogy nem várható el sem Thaiföldtől, sem bármelyik más országtól, hogy egyedül oldjon meg egy regionális menekültválságot. A menedéknyújtás humanitárius, emberiességi parancsa előbb-utóbb összeütközésbe kerül az állami szuverenitással és az adott állam gazdasági teherbíró képességével. Mindezért, a jogi eszközökön túl a nemzetközi közösség együttmüködésére és ezzel kapcsolatos mechanizmusok kidolgozására lenne szükség.

\section{Irodalomjegyzék}

Amnesty International: Thailand: Between a Rock and a Hard Place (2017. szeptember 28.). Online: www.amnesty.org/en/documents/asa39/7031/2017/en/

ASEAN: Human Rights Declaration (2012. november 19.). Online: https://asean.org/asean-humanrights-declaration/

Asian-African Legal Consultative Organization: „Final text of AALC's 1966 Bangkok Principles on Status and Treatment of Refugees" as adopted on 24 June 2001 at the AACLO'S 40 th session, New Delhi (2001). Online: www.aalco.int/Final\%20text\%20of\%20Bangkok\%20Principles.pdf

Bandow, Doug: Desperate Pakistani Christians Languish in Thailand. Cato Institute, 2018. október 29. Online: www.cato.org/commentary/desperate-pakistani-christians-languish-thailand Chantavanich, Supang - Paul Rabe: Thailand and the Indochinese Refugees: Fifteen Years of Compromise and Uncertainty. Southeast Asian Journal of Social Science, 18. (1990), 1. 66-80. Online: https://doi.org/10.1163/080382490X00042

61 Szakáli (2018): i. m. II.2.4. fejezet. 
Chia, Jasmine: Detention centres stuck in past century. Bangkok Post, 2018. február 18. Online: www.bangkokpost.com/thailand/special-reports/1414047/thailands-detention-centres-stuckin-past-century

Chotinukul, Jittawadee: Thailand and the National Screening Mechanism: A Step Forward for Refugee Protection? The Global Migration Research Paper Series 25, 2020. Online: www.graduateinstitute.ch/sites/internet/files/2020-09/Edited\%20Paper_Thailand\%20\%26\%20NSM_Final.pdf

Davies, Sara Ellen: Legitimising Rejection: International Refugee Law in Southeast Asia. After the 1979 Conference: the Early 1980s. Leiden, Brill Nijhoff, 2007. Online: https://doi.org/10.1163/ ej.9789004163515.i-288

European Commission: Thailand, Malaysia, and Indonesia (2019. július 5.). Online: https:// ec.europa.eu/echo/where/asia-and-pacific/thailand_en

Global Detention Project: Thailand (2021). Online: www.globaldetentionproject.org/countries/ asia-pacific/thailand

Halmai Gábor - Tóth Gábor Attila: Emberi jogok. Budapest, Osiris, 2003.

Hárs Ágnes: A nemzetközi migráció néhány problémájáról. Szakirodalmi áttekintés. Szociológiai Szemle, 2. (1992), 2. 123-137.

Human Rights Watch: Two years with No Moon. Immigration Detention of Children in Thailand (2014. szeptemer 1.). Online: www.hrw.org/report/2014/09/01/two-years-no-moon/immigration-detention-children-thailand

Human Rights Watch: Re: Pakistani asylum seekers in Thailand (2018. november 6.). Online: www. hrw.org/sites/default/files/supporting_resources/181105_unhcr_thailand_pm_letter_1.pdf

IOM UN Migration: United Nations Launches Thailand Migration Report 2019 (2019. január 25.).

Online: www.iom.int/news/united-nations-launches-thailand-migration-report-2019

Környei Ágnes: Emberi jogok a nemzetközi kapcsolatokban. Piliscsaba, Pázmány Péter Katolikus Egyetem, 2011. Online: https://btk.ppke.hu/uploads/articles/4090/file/kornyei_agnes-emberi_jogok_a_nemzetkozi_kapcsolatokban(1).pdf

Leekpai, Chuan: Opening Statement - Regional Meeting for Asia, United Nations World Conference on Human Rights. Bangkok, Thaiföld, 1993. március 29. - április 2. UN Digital Library, 1993.

Mantāphọn, Withit: The Core Human Rights Treaties and Thailand. Brill, 2016. Online: http://cat. lib.unimelb.edu.au/record=b6272707 S30

Ministry of Tourism and Sport: Tourism Statistics 2017-2021. Online: www.mots.go.th/mots_en/ more_news_new.php?cid=336

Office of the Council of State: Immigration act, B.E. 2522. 1979. (1979). Online: http://thailaws. com/law/t_laws/tlaw0127.pdf

Rajaram, Prem Kumar - Carl Grundy-Warr: The Irregular Migrant as Homo Sacer: Migration and Detention in Australia, Malaysia and Thailand. International Migration, 42. (2004), 1. $33-$ 64. Online: https://doi.org/10.1111/j.0020-7985.2004.00273.x

Ravenstein, Ernst George: The Laws of Migration. Journal of the Statistical Society of London, 48. (1885), 2. 167-235. Online: https://doi.org/10.2307/2979181

Refugee Legal Aid Information for Lawyers Representing Refugees Globally: Refugee protection in the Asia Pacific region (2021). Online: www.refugeelegalaidinformation.org/refugee-protectionasia-pacific-region

Rogers, Chris: The Christians held in Thailand after fleeing Pakistan. BBC News, 2016. február 26. Online: www.bbc.com/news/magazine-35654804 
Rungthong, Waritsara: Thailand's National Screening Mechanism: Key Issues. Opinion Juris, 2020. január 28. Online: https://opiniojuris.org/2020/01/28/thailands-national-screening-mechanism-key-issues/

Szakáli Máté: Az emberi jogok egyetemességének dilemmája és a délkelet-ázsiai jogvédelmi mechanizmus evolúciója. PEACH Mühelytanulmányok, (2018), 20.1-33. Online: https://btk.ppke.hu/ uploads/articles/447809/file/wp/peach_wp_20_szakali_emberi_jogok.pdf

Thailand's Constitution of 2017. 2017. Online: www.constituteproject.org/constitution/Thailand_ 2017.pdf?lang=en

The Global Economy: Refugee population in South East Asia (2020). Online: www.theglobaleconomy.com/rankings/refugee_population/South-East-Asia/

UCA News: Caged like animals: Inside Bangkok's notorious IDC. Union of Catholic Asian News, 2020. január 30. Online: www.ucanews.com/news/caged-like-animals-inside-bangkoks-notorious-idc/87104

UN CAT Committee: Concluding observations on the initial report of Thailand (2014. június 20.)

UNCRC: General comment No. 6 (2005): Treatment of Unaccompanied and Separated Children Outside their Country of Origin. (2005. szeptember 1.)

UNCRC: Concluding Observations, Thailand (2012. október)

UNHRC: CCPR General Comment No. 17: Article 24 (Rights of the Child) (1989. április 7.)

UNHRC: CCPR General Comment No. 20: Article 7 (Prohibition of Torture, or Other Cruel, Inhuman or Degrading Treatment or Punishment) (1992. március 10.)

UNHRC: CCPR General Comment No. 21: Article 10 (Humane Treatment of Persons Deprived of Their Liberty) (1992. április 10.)

UNHRC: General comment No. 35, Article 9 (Liberty and security of person). (2014. december 16.)

UNHCR: Thailand Factsheet (2016. január). Online: www.unhcr.org/protection/operations/50001e 019/thailand-fact-sheet.html

UNHRC: Concluding observations on the second periodic report of Thailand (2017. április 25.)

UNHCR: UNHCR welcomes Royal Thai Government's commitment to release of detained children in Thailand (2019. január 21.). Online: www.unhcr.org/th/en/16809-unhcr-welcomes-royal-thaigovernments-commitment-to-release-of-detained-children-in-thailand.html

UNHCR Executive Committee of the High Commissioner's Programme: Update on budgets and funding (2020-2021) (2021. március 4.). Online: www.unhcr.org/605c429d4.pdf

UNHR: Thailand (é. n.). Online: www.ohchr.org/EN/Countries/AsiaRegion/Pages/THIndex.aspx

UNICEF: Convention on the Rights of the Child. General Assembly resolution 44/25. (1989. november 20.). Online: www.unicef.org/child-rights-convention/convention-text

Universal Periodic Review: 2RP: Responses to Recommendations and Voluntary Pledges. Thailand (2016. május 11.). Online: www.upr-info.org/sites/default/files/document/thailand/session_25_-_may_2016/recommendations_and_pledges_thailand_2016.pdf

UNWTO: Thailand: Country-specific: Basic indicators (Compedium) 2015-2019 (2020. november). Online: www.e-unwto.org/doi/epdf/10.5555/unwtotfb0764010020152019202011

Werrett, Ian: Protecting Vulnerable Children in Thailand. Thailand Law Journal, 17. (2014), 1. Online: http://thailawforum.com/articles/rights-of-refugee-children-in-thailand.html

World Bank: International tourism, number of arrivals (2019). Online: https://data.worldbank.org/ indicator $/$ ST.INT.ARVL?locations $=\mathrm{TH}$

World Tourism Organization: Compendium of Tourism Statistics, Data 2014 - 2018, 2020 Edition (2020). Online: https://doi.org/10.18111/9789284421459 